second part. Some home problems, such as industry and its organization and control, demobilization, ex. ports, social insurance, housing and agriculture, health and educational services are briefly indicated in the third. The second chapter indicates some of the implications of the Atlantic Charter in such matters as relief and rehabilitation in Europe and the Middle East, the significance of the Hot Springs Conference, the potentialities of the Middle East Supply Centre, the problem of Germany and the special problems of the British Empire, such as the co-ordination of foreign policy and defence and trends in colonial welfare and development. Although necessarily sketchy, the pamphlet succeeds in indicating the relation of particular problems to the larger issues, and the problems of home and international policy, on the solution of which Britain's economic stability, social security and future prosperity depend.

\section{Typhus in Guatemala}

The July issue of the Boletin de la Oficina Sanitaria Panamericana contains an account of an outbreak of typhus by Dr. Julio Roberto Herrera, head of the Section of Epidemiology of the General Health Office of Guatemala. He stated that he received on April 3, 1944, a notification of 198 cases of an infectious disease, which turned out to be typhus, in a home for the insane, a general hospital and a penitentiary. There were altogether 198 cases with 63 deaths. The case fatality for the home for the insane was $26 \cdot 10$ per cent. Preventive measures included quarantine of the foci, restriction of visits, disinfection and disinsectization of the hospitals, barracks, etc., verification of definite and suspected cases by public health laboratories, visiting of all contacts, immunization of exposed staff, examination of autopsy specimens, organization of a national disinfection station, education of the public by the Press, radio, etc., isolation of cases and supervision of hospitals and welfare stations.

\section{British Dragonfly Records}

Miss Crnthia Longfiedd, British Museum (Nat. Hist.), Cromwell Road, London, S.W.7, writes: "As I shall be revising for publication, in the very near future, the records on distribution of all the British dragonflies, I shall be most grateful if all collectors, who have not done so already, will send me their lists of localities, including approximate status, of dragonflies identified up to the end of 1944. Observations on habitats, definite proof of breeding and methods of oviposition will be most valuable. All help will be gratefully acknowledged."

\section{Royal Institution: Graduate Memberships}

THE first three of the graduate memberships recently established by the Managers of the Royal Institution for recent graduates, of either sex, of any university in the British Empire who have obtained first- or second-class honours in any scientific subject, have just been awarded. The fecipients are : Miss June M. Broombead, who gained a major scholarship in 1941 and a research scholarship in 1944 at Newnham College, Cambridge, and was placed in Class II (1) in the Natural Sciences Tripos in physics, 1944 ; Mr. Robert B. Morrison, who took first-class honours in physics in the University of London, 1944, and is now University demonstrator at King's College; and Mr. Anthony P. Waterson, who took a first class in Part I of the Natural Sciences
Tripos, Cambridge, 1943, and in Part II (biochemistry), in 1944. $\mathrm{He}$ is studying medicine at the London Hospital.

\section{Royal Aeronautical Society : British Empire Lecture}

TнE Council of the Royal Aeronautical Society has recently completed arrangements for the founding of a British Empire Lecture. The Lecture, on any aeronautical subject approved by the Council, will be delivered annually in September in London, by a. lecturer chosen in alternate years from the British Dominions and Colonies and Great Britain. The Society, by founding the Lecture, is anxious to encourage new ideas and new points of view from all parts of the British Empire, and to make the lecture second in importance only to the Wilbur Wright Memorial Lecture. The British Empire Lecture will have a premium of $£ 50$ attached to it, and in the case of lecturers coming from the Dominions and Colonies an allowance up to $£ 100$ will be paid towards the lecturyr's expenses. It is proposed to hold the first lecture in September 1945, and suggestions for lecturers should be received by May 31, 1945, at the latest.

\section{University of London Appointments}

Dr. L. S. Penrose has been appointed to the Galton chair of eugenics tenable at University College. Since 1939 he has been attached to the Provincial Department of Health, Ontario, Canada, and in addition is a physician at the Ontario Hospital, lecturer in psychiatry in the University of Western Ontario, and medical statistician for the Province.

Dr. C. Rimington, who has been on the staff of the National Institute for Medical Research since 1937, has been appointed as from May 1 to the Eniversity chair of chemical pathology tenable at University College Hospital Medical School.

\section{Announcements}

WE regret to announce the following deaths :

The Earl of Balfour, P.C., chairman of the Cambridge committee of the Commission on the Universities of Oxford and Cambridge, on January 14, aged ninety-one.

Sir Thomas Barlow, Bart., K.C.V.O., F.R.S., president in 1910-15 of the Royal College of Physicians, on January 12, aged ninety-nine.

The Committee of the Athenæum has elected the following, under the provisions of Rule II of the Club, which empowers the annual election by the Committee of a certain number of persons of distinguished eminence in science, literature or the arts, or for their public services : the Right Hon. Lord Catto of Cairncross, governor of the Bank of England; Sir Bennett Melvill Jones, Francis Mond professor of aeronautical engineering, University of Cambridge ; the Hon. John Gilbert Winant, ambassador of the United States to the Court of St. James's.

Dr. Dellepiane Rawson, an eminent plastic surgeon in the Argentine, has arrived in Britain for a six months visit arranged by the British Council. Dr. Rawson, who is head of the special ward for plastic and restorative surgery at the Hospital Rawson, Buenos Aires, and associate teacher at the Faculty of Medicine, will be working with Sir Harold Gillies in the Emergency Medical Service Plastic Surgery Unit at Park Prewett Hospital, Basingstoke. 